\title{
Overview of the Italian architecture in Durrës from 1920 to 1944
}

\author{
Loreta Çapeli $^{1}$, Meri Priftuli Semini ${ }^{2}$, Florian Nepravishta ${ }^{3}$ \\ 1,2,3 Polytechnic University of Tirana, Faculty of Architecture and Urbanism, Rruga. M. Gjollesha, 54, Tirana, Albania
}

\begin{abstract}
Durrës is an Albanian coastal city. During the period from 1920 to 1943, Italian architects examined his urban plans and proposed new ones. The architectural heritage of Italian style and its monumental structures built during the '30 s in Albania possess precious architectonic and cultural elements that must be preserved and promoted and to achieve that, we may start by first identifying and presenting them to the wider community of interested professionals. This study identifies these buildings, their location in the city and focuses on the small structures with residential function, highlighting their architectural qualities. Through the study cases on the villa typology the aim is to explain and know the morphology, compositional and stylistic characteristics. Concluding, it has been understood that Durrës city encloses inside its structure a lot of architectonic value that, as an inherited richness must be protected, restored, and evaluated, prior to being damaged from lack of attention. Also, the data of this study will serve for future restoration interventions in order to help the revaluation of the architectonic and urban landscape.
\end{abstract}

Keywords: Heritage, Italian architecture, Residential, Durrës

\section{Historic Background}

The city of Durrës due to its favorable geographical position on the Adriatic shores has been a very important city since the antiquity. Around the $7^{\text {th }}$ Century BC it was known as Epidamni but later, in the $4^{\text {th }}-2^{\text {nd }}$ Century BC as Dyrrah. It had a remarkable economic growth and social development during the Roman Empire Period.

During the $1^{\text {st }}$ Century BC, it became the starting point for the Via Egnatia, a major arteria that connected east and west; an Amphitheatre of 15-20,000 seats was built, together with the fresh water supply Aqueduct, the Library, and other buildings for social as well as for religious use.

Later on, during the Byzantine period (395-1341) the city of Dyrrah continued to play its role as one of the most important cities in the area and as the capital of the province of New Epirus. During this period, under the rule of the Emperor Anastasio the First, the city's defensive walls surrounding the city, were built. [1] During this period were also built the Forum and the Basilica, mentioned in the ancient sources and verified through archeological remains. After e few disastrous earthquakes, there were the Anjuin's and later on were the Venetians who repaired, adapted and maintained the imposing towers of the defensive wall.

The city of Durrës continued to be one of the most important centers of the Arber state but, following the Turks invasion in 1501 , the city was almost abandoned and turned into an inhabited center of one hundred houses. [2] Only during the $17^{\text {th }}$ Century the city started to regain its former role as a commercial center slowly.

In 1912, the city proclaimed its independence and this event signed the end of the Turks rule over the city. During the three decades that followed, till the end of the Second World War, the city went through another period of vigorous growth and development. It was the second most important city after the capital of Tirana. Its strategic position in the
Adriatic Sea, with its harbor and the trade that follows, has been a source of income and economic prosperity that always has supported a rich structure, and we could say, a modern architecture deeply influenced by the advanced European cultures of the time.

The aim of this study is to identify the important structures built during the beginning of the $20^{\text {th }}$ Century in order to understand their architectural values and, through acknowledgment, to promote their evaluation as a cityes cultural heritage, which must be protected.

\section{Urban Plans up to 1942}

At the beginning of the $20^{\text {th }}$ Century, the city of Durrës, like many other Albanian cities, inherited a medieval appearance. Built in a spontaneous way over the old city of Dyrrachium, the city of Durrës had not a regular urban system, but used its position near the sea as a favorable element to help the city connection with the world.

That first urban situation came through the assessment city plan of the year 1928 (figure 1.a.) which reflected a medieval urban shape organized. The triple roads that ended at the regular shape square, gave this square the important organizational role for the city, as it was usually the case with all medieval cities which were organized around the religious buildings.

After this time, with the establishment of intensive relations between the Albanian and the Italian Kingdom, Italian architects and engineers came in Albania. They revised the urban studies made by Austro-Hungarian architects during the First World War and, eventually, proposed new plans for the Albanian cities with the intention to give these cities a modern and European appearance and structure. 


\section{International Journal of Science and Research (IJSR) ISSN (Online): 2319-7064}

Index Copernicus Value (2013): 6.14 | Impact Factor (2014): 5.611

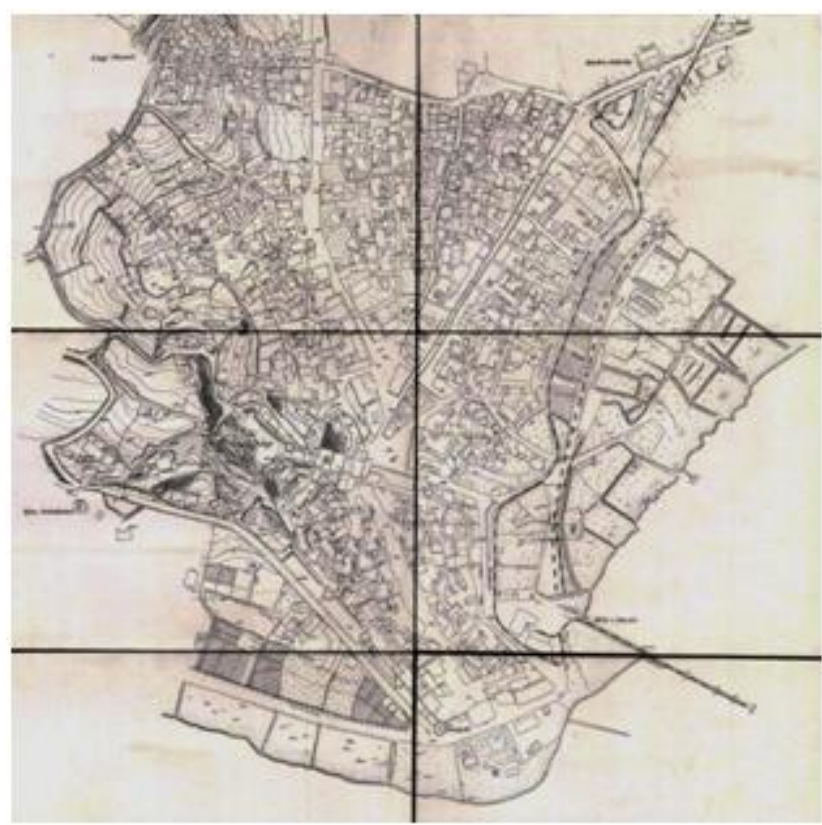

Figure 1, a) Assessment city plan 1928, [3]

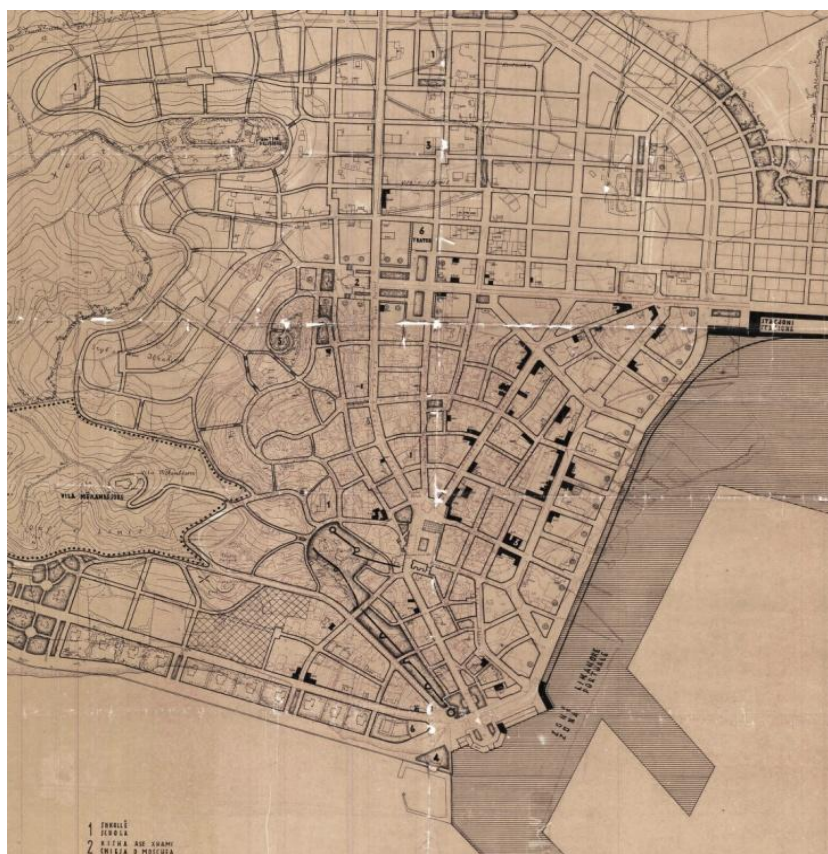

Figure 1: b) Regulatory city plan 1942, [3]

First, in 1934, a group of architects led by G. Bertè, prepared a Regulatory Plan for Durres city, but it was not implemented [3]

In 1937, a general survey of the urban area was conducted so that it could serve as a support for the next General Regulatory Plan.

Following this period, another plan was prepared by the Italian architects L. Carmignani and F. Poggi and it was approved in 1942. [4] It preserved the main logical structure of the 1934 plan, and proposed a perpendicular road system mainly for the new northern part, where the development of the city was foreseen. (Figure 1, b)

Important interventions consisted in the Main Square in front of the Town Hall, planned for some administrative buildings.
[5] Remodeling the previous urban center, it preserves it and accepts the sacred building as an important part of it. The shape of the square is regular and, through the side flower garden, includes the existing mosque building in the compositional scheme. (Figure 2).

The buildings facing the square reflect the tendency of architecture, according to the rationalist Italian stream of the time, and not a repetition of the Renaissance architectural orders and styles.

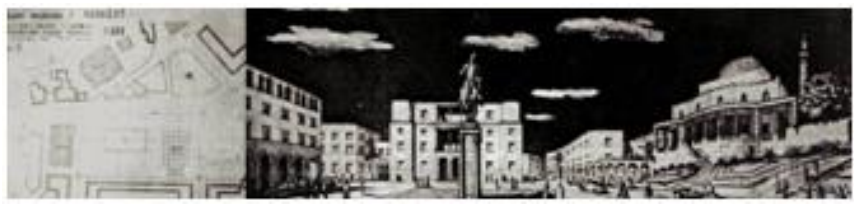

Figure 2, Plan and perspective view of Town Hall square.

[4]

Note the increase in the number of approved buildings that were placed mainly along the main roads and the harbor square which has taken its final form together with its surrounding buildings.

Note also the trace of the "Mercantile Street" that played a very important part in the network of streets. This street was already well defined in the 1928 and began from the southeast at the gate of the harbor and went straight northwest, up to the City Hall square. (Figure 3)
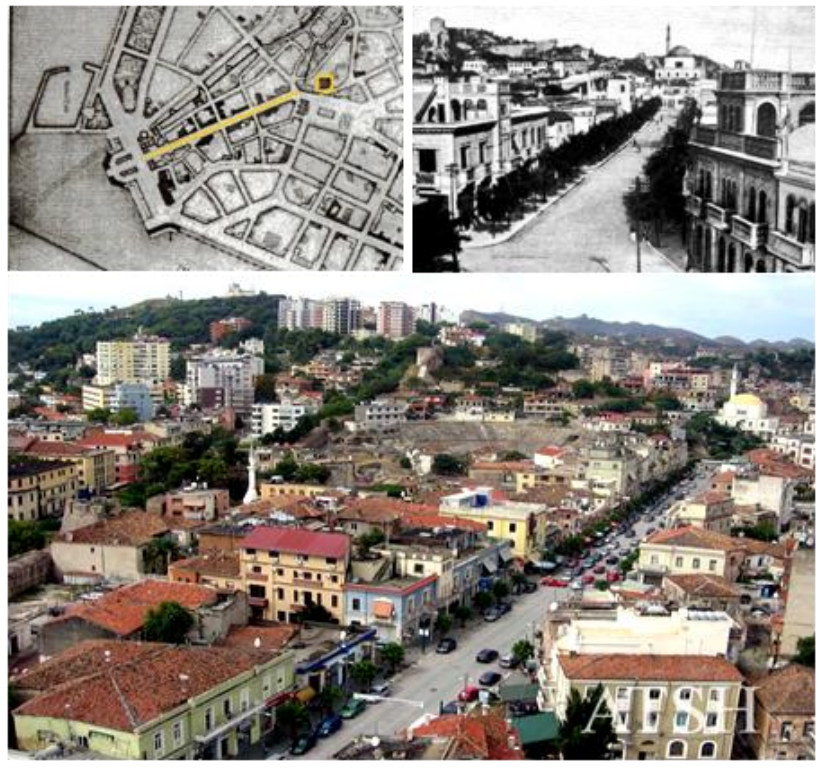

Figure 3. Plan and aerial view of old and new "Mercantile Street"

Source: [3], [6], [7]

So the religious building remained an urban focus even for the "Mercantile Street" which, at the end of its perspective, used the Mosque as an architectonic sign: A baroque concept of an open city to be seen in Durrës urban texture.

\section{Architectural Appreciation}

According to the 1942 plan, there was a requalification effort on the city main streets and new constructions of buildings with mixed residential and commercial use while 


\section{International Journal of Science and Research (IJSR) \\ ISSN (Online): 2319-7064 \\ Index Copernicus Value (2013): 6.14 | Impact Factor (2014): 5.611}

maintaining the construction limit line and the height of the buildings up to 2-3 storeys high.

The buildings of this time fall into two categories - Public and Residential, while in the category of residential structures we find the subdivision of Single family dwellings and Collective residential buildings. Up to date there have been identified 76 structures.

Along the sides of the "Mercantile Street", there are buildings that reach the border of the sidewalk creating the image of the corridor street. Some of these are in a NeoClassical or Eclectic style (built before 1926), but others reflect a modern architecture clearly influenced by the principles of Italian rationalism (built after 1926). The 1926 earthquake demolished some of these buildings which, later were reconstructed in a new architectural style.

Along this street, the buildings are preserved in good condition due to a recent intervention of the City Hall, which aimed at the facades restoration by plastering and painting them. However, in other cases of private interventions, sometimes we can detect non proper restorations which transform the architectural identity.

The study deals with this particular architectonic value. It throws light over it by listing and classifying the façades and their minor details like the doors and the windows.

Used for business activity, the ground floors of buildings were rich in architectonic details, mostly in line with a sense of laconic rationalism. We find a sense of play in the frames around doors and windows, mainly of rectangular shape, made of plaster mimicking the carved stone that are combined with the horizontal thick lines on the facades. (Figure 4.a) The architectonic order is rarely used, even where the pylons decorate the spaces between openings; they are only styled capitals or bases

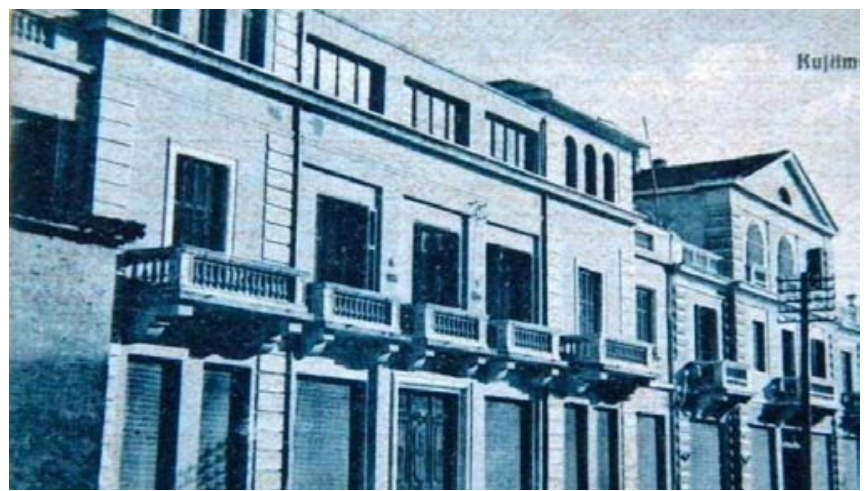

Figure 4: a) Rectangular Openings, [6]
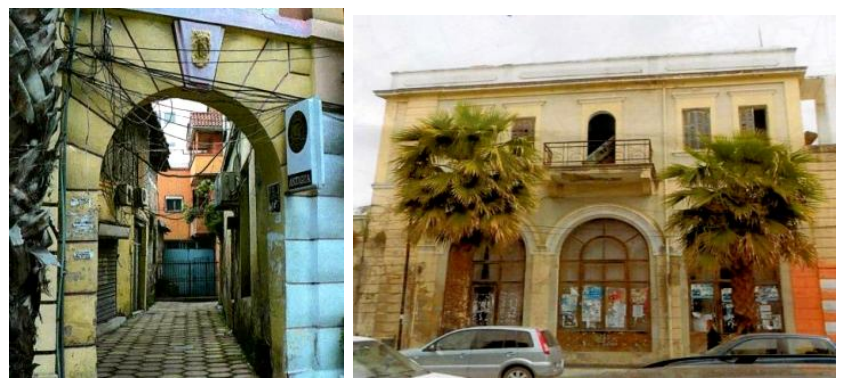

Figure 4: b) Vaulted shape openings, source Authors
The vaulted shape openings in the ground floor are rarely used, but sometimes they are preferred for a street-door opening to connect, access to, or from the main street. (Figure 4.b)

A preferred detail for the enrichment of the main facade are the balcony parapets which are composed of prefabricated concrete elements with vertical or curved lines which, in an original and authentic game of forms, remind us of the sea waves.

Seldom are found iron railings as a balcony parapet, but otherwise the iron was the material used mainly for the door's decoration. Similar details to the balconies are found to be repeated on the upper balusters that aim to unify the architectonic image with their horizontal cornices.

Another interesting part of the study are the details embellishing the windows, which are mainly of rectangular opening shape with side frames of carved surfaces.

These carved lines will help the framing to be more visible in the whole view of the building facade. There are few arched windows and, when used, are of double and triple aisles, bringing a romantic atmosphere in the building façade. (Figure 5,a)
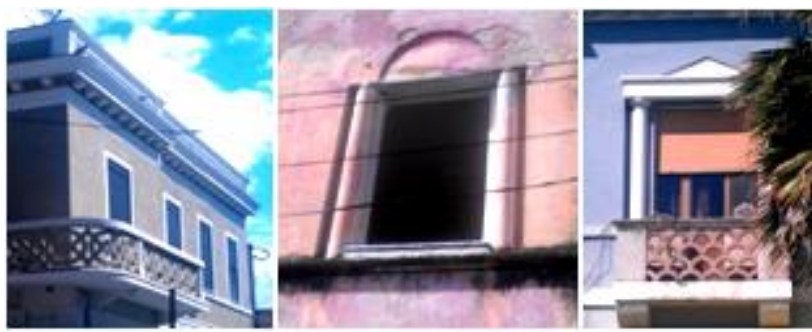

Figure 5: a) Windows details in Durrës [8]

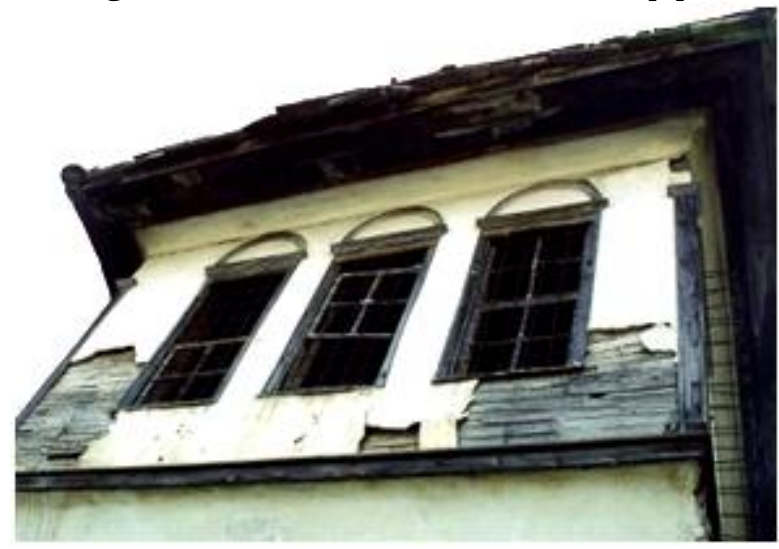

Figure 5: b) Traditional house, Gjirokaster. [8]

Another window type is a rectangular one, decorated by two small side columns and a blind arch above the beam, (Figure 5 ,a) which is strange to the decorating style of the Italian rationalists, but seems more a reminiscence of the local use of painted wooden arches over the windows beam in the traditional house of Gjirokastra. (Figure 5,b)

Following historical data, we remind the fact that the Italian architects were amazed by the richness of vernacular architecture of the local traditional buildings [4], which tried to introduce it, in a stylized form, into their detail designs 


\section{International Journal of Science and Research (IJSR) \\ ISSN (Online): 2319-7064}

Index Copernicus Value (2013): 6.14 | Impact Factor (2014): 5.611

\section{Deterioration Stage}

The conditions of the buildings of that period are not uniform in different parts of the city. While the main streets such as the "Mercantile Street" or the "Main Boulevard," benefited from the attention of the public administration with funds to restore the facades, the others suffered from lack of maintenance and suffered physical deterioration.

This study examines a interesting zone of the city, on the right side of the Venetian Tower, Defensive Wall and Amphitheatre, as a "Study Site," in order to analyze in a case by case way all the buildings that are still standing by that period of time. (Figure 6, a)

This area, near the tourist area of the city, is today transformed and has a lot of buildings with advanced degradation or buildings that defy and transform the architectural language of the original settlement.

This study aims to examine also the structures that may have been destroyed during the past twenty years.

Following the decided methodology, for each buildinges assessment, it was prepared a Bibliographical Index (Figure 6, a) containing: the existing urban situation, the building plan layouts, the historic archive materials and buildinges exterior, interior and detail pictures of the actual condition. Then we scheduled them in a database ready to be used in another study step.

At the beginning of the area, alongside of the Venetian Tower, is Hotel „Vollga ${ }^{\text {ee }}$ former „Albergo dei Dogiee one of the symbols of the City, built in two years from 1938 to 1940. It had a built area of 3400 square meters, which is now entirely abandoned and degraded.

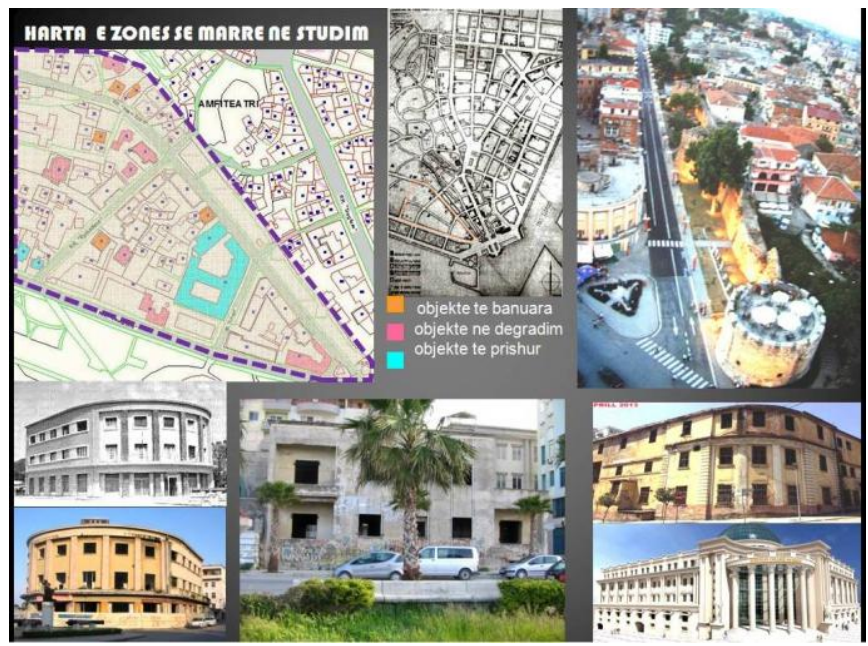

Figure 6: a) Bibliographical Index of "study site" [8]

Continuing in the Taulantia Street, we find another building that has housed the archeological museum up to the 1990, but today is completely degraded. Further on, in the map of the year 2000 , we can spot other objects of this period, today demolished to be replaced by high-rise commercial and residential buildings.

Another building that defines the area of study is the former
Tobacco Factory „Stamles "e built in 1924 which was famous as the biggest factory in the Balkans, but on its place today we see another structure with an entirely different architectonic language.

Continuing the street, on the side of the amphitheatre we find four buildings that one year before were inhabited, but today is deserted and risk demolition.

Building No. 1. (Figure 6, b) Its location at the crossroad has played a significant role and has constrained its layout and its interior partitions. The central access vestibule is of irregular hexagonal shape and will become an organizational focal point for the building.

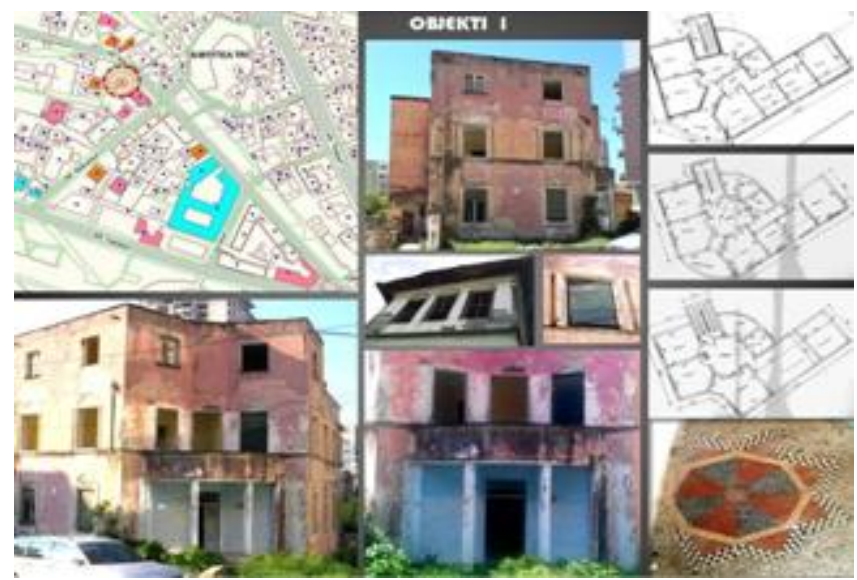

Figure 6: b) Bibliographical Index of building 1[8]

The rest of the interior partitions are distributed on both wings with a view on the street. A perspective view of the road from the hill could be a very disturbing and repulsing sharp corner, but the architects have ,carved ${ }^{\text {ee }}$ this sharp corner to make space for a welcoming small ,piazza.' They clearly signal the access point into the building and is covered with the only balcony of the building that is supported by two columns.

The exterior is treated with a clear and concise language. The esthetics of the facade rely on proportional harmony of the principal elements and a few decorative details. The ground floor windows, differentiated from those of the upper floor level, have only decorative frames, while those above have additional small columns on the sides as a replica in miniature of the columns supporting the balcony at the access door and a blind arch above as a decorative supplement. (This detail has been applied in other areas in Durrës).

Following a careful survey of the exterior, we can see that an additional floor has been built on top of the building, being deprived of the upper decorative cornice similar to the one dividing the ground and first floor. In the interior spaces, we can still see the careful work in detail of floors that were equipped with mosaics.

Building, No. 2. (Figure 7,a) Being positioned in the corner of its parcel plot, the building is not constrained by its peculiar position. In its layout composition, it is similar to a two - family villa.

\section{Volume 5 Issue 7, July 2016 www.ijsr.net}




\section{International Journal of Science and Research (IJSR) \\ ISSN (Online): 2319-7064}

Index Copernicus Value (2013): 6.14 | Impact Factor (2014): 5.611

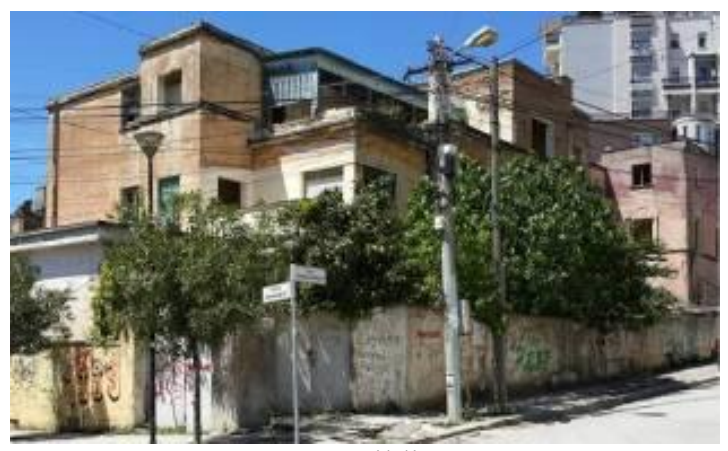

Figure 7: a) Building $\mathrm{N}^{\circ} 2$, [8]

The exterior decoration is essential and limited to the horizontal cornices that limit the window height. The volumetric movement of the building has been lost in time through the usual addition of another upper storey, occupying the space previously reserved to the two panoramic terraces, it once had.

Building, No. 3. (Figure 7,b) It has a simple layout plan and is composed of a half - underground floor and two upper floors, distributing areas on the sides of the linking corridors.

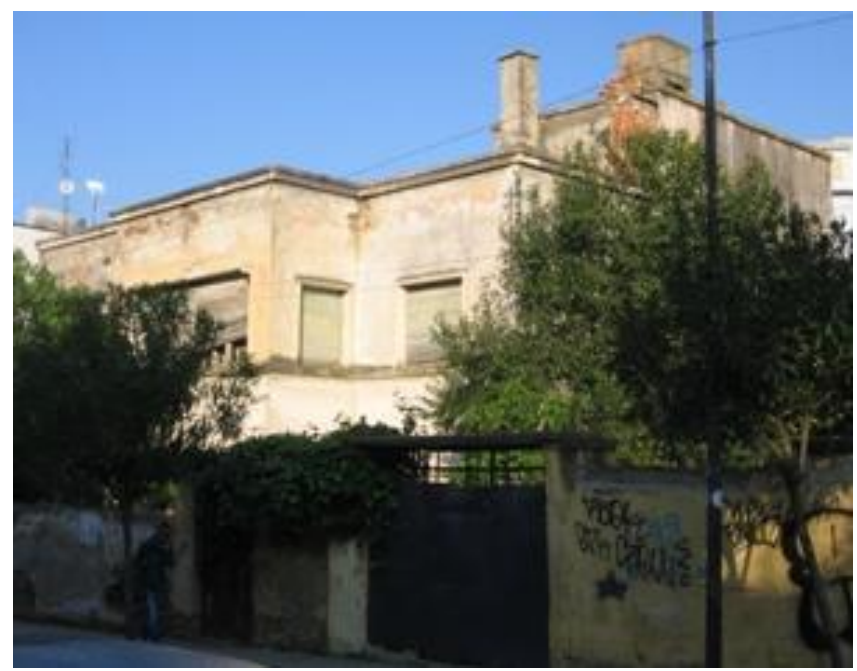

Figure 7: b) Building $\mathrm{N}^{\circ} 3[8]$

As for the architectonic style, the structure shows a similar approach with the nearby villa replicating the same decoration featuring horizontal cornices and the same movements of volumes and the same terraces with panoramic view. The window openings are significant, thus offering very good sun exposure of the rooms in the south east side. Long years of neglect and abandonment have taken their toll and the building now is inaccessible and degraded.

Building, No. 4. (Figure 7,c) In the assessment plan of 1928, it exists as a constructed plot. The architectonic language of the facade and the window proportions are some of the elements that leave a doubt on the time of construction as it has much more in common with the ottoman buildings or to eclectic ones.

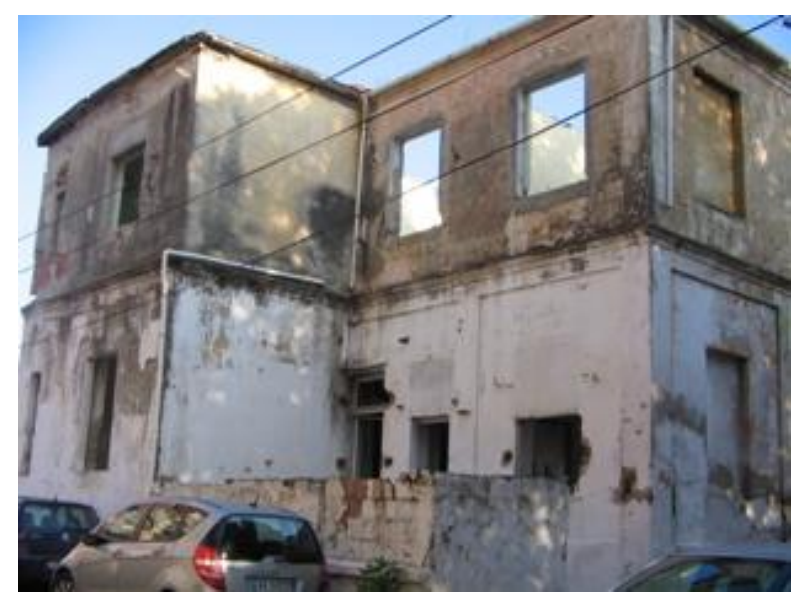

Figure 7: c) Building $\mathrm{N}^{\circ} 4,[8]$

Based on the way the plan was composed and how the facade was treated, we think that this building was changed from a single storey building with a pitched roof, to a two storey one.

The presence of an outer staircase that leads to the upper floor is an indication of the new floor extension, together with the detailed cornice that frequently is found just under the pitched roof and now is between the two storeys, or the pilasters that are not replicated in the upper floor.

The periods of construction and extension remain to be cleared. The street leading to the King Zog Villa does not offer a better view. At the sides of the city and in its proximity, during the last twenty years the constructions have violated the architectural image creating a confusion of forms and volumes without criteria. At the street end, after a deviation towards the hill's top, is the Villa of King Zog, once a dominating panorama view, while now it is neglected and immersed in a disturbed environment of constructions.

The construction of the King Zog Villa in Durrës, with an amazing, beautiful architecture for its time, was completed in 1943. (Figure 8) For its building and furnishing, it was spent the fortune of 1.5 million golden francs, a sum equal to the construction of each of the Ministerial Complex buildings in Tirana.

During the civil unrest of 1997, this villa was emptied from its furniture and suffered the loss of many of its valuable decorations reducing it to a degraded building. 


\section{International Journal of Science and Research (IJSR) \\ ISSN (Online): 2319-7064}

Index Copernicus Value (2013): 6.14 | Impact Factor (2014): 5.611

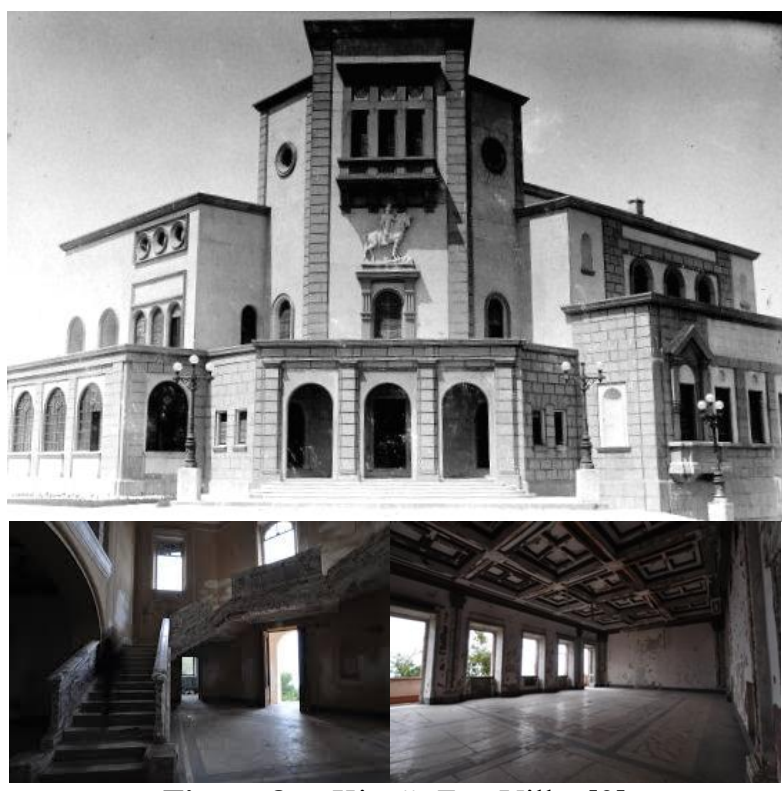

Figure 8: Kinges Zog Villa, [9]

\section{Remarks and analyzes of actual interventions}

Today, we sincerely regret the degradation of an important history part, because with the passing of time, a lot of buildings have lost their original design.

The former Hotel "Vollga" shows a remarkable architect"s sensibility to replicate the morphologies of the Venetian tower, due to his closer presence. (Figure 9, a) While, the recent structures do not take care to respect these elements, resulting to an architectonic violation of the historic city urban space, and its historic skyline. (Figure 9, b,c,)

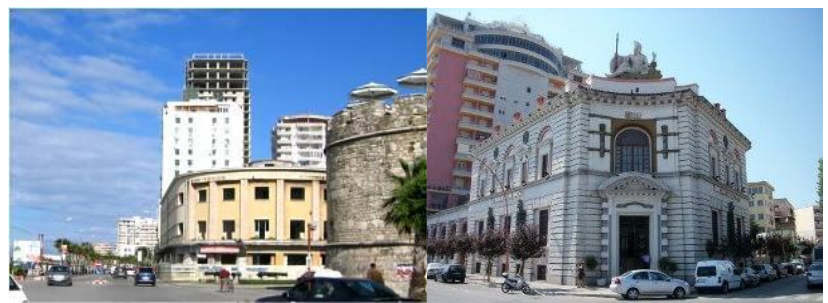

Figure 9: a) Hotel Vollga [8] , b) Bank of Albania Building. [8]

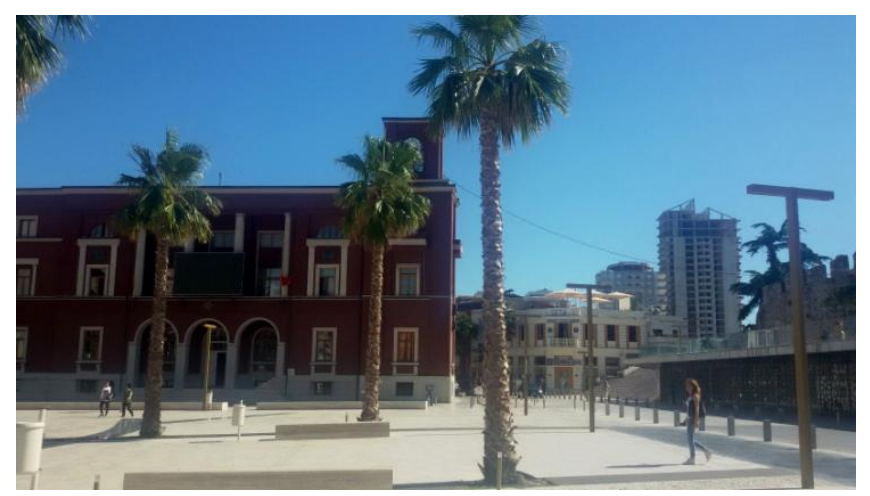

Figure 9 : b) Town Hall Square, central square [8]

Interventions without criteria have violated the architectonic image of historic buildings and squares. In the city history, it is important not only its architectonic image, but also the visual and historic citizen"s memory, which must be respected. Important points of the city like „Vollga“ and the Venetian Tower are now cardinal points for the city life. They must continue to play this historical role. The necessity and the actual pressure to build new structures for business or residential purposes should be addressed to the new construction plots, strictly away from historic sites and places. Sometimes, due to the lack of historical studies, the reconstructions have harmed the architectonic language of the buildings they aimed to improve. For those structures, where the intervention is not yet finished, it must be immediately intervened, based on the historical studies, to help with the correct treatment of architectonic details. Attention should be given to buildings in good shape, but that often come with deviations of their architectonic details, which mistakes can be treated as original. (Figure 10,) By studying the old images and the most degraded parts of the building, it should be possible to distinguish the original elements and to intervene to return it in his historic shape.

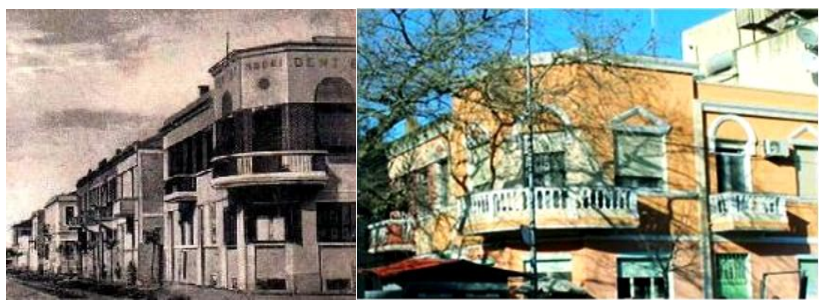

Figure 10, Old view [6] and Details [8] of the same building, mistakenly treated

\section{Conclusions}

Durrësi is a historical city remembered for two important architectural periods: The antiquity one and the twentieth century Italian influence. The first period is buried, mostly, under the new city. It disappeared in the course of time. From the second period, there are still some standing buildings and squares. Most of them are waiting to be rescued by the state. Italian rationalism architecture during the XX century in Albania is a patrimony that does not belong only to the Albanians, so that it should be preserved, restored and re-evaluated in order to be part of the national cultural heritage before that it could be damaged or lost by lack attention.

\section{References}

[1] Miraj, L., (1983) "Mbi muret mbrojtese parabizantine te Dyrrahut", MSAD, (Durres 1983), pp.100-108.

[2] Hoti, A., (2003). "Durresi (Epidamni, Dyrrahu)", Julviu 2, Tirane 2003, pp 20-40

[3] AQTN - Arkivi Qendror Teknik i Ndertimit,Tirane,

[4] Giusti M. A., (2006). "Albania, Architettura e Citta, 1925-1943, Bandecchi \& Vivaldi, Pontedena, Firenze. pp 13-15, 67-79, 189-191

[5] Menghini A.B., Pashako, F., Stigliano, M., (2012) "Architettura Moderna Italiana per le Citta D"Albania. Modelli e interpretazioni.” DUDAJ/Collona Archinauti 40,Tirane 2012, pp 65-66, 75-78

[6] Private collection

[7] Agjensia Telegrafike Shqiptare (ATSH)

[8] Author"s design or photo

[9] [On line] Available byhttp://www.skyscrapercity.com 


\section{International Journal of Science and Research (IJSR) \\ ISSN (Online): 2319-7064}

Index Copernicus Value (2013): 6.14 | Impact Factor (2014): 5.611

\section{Author Profile}

Loreta Çapeli is a lecturer of the History of Architecture at Faculty of Architecture and Urbanism of Tirana, from 1995 to date. She received a M.S. degree in Architecture (1991), a Post Master degree in "Architectural Survey and Documentation Restoration of Architecture" (2006) and she is a Phd candidate in the historical study of the architectonic typologies from antiquity. Her main areas of research are the History of Architecture, both, of the World and the Albanian one, also the critics and the architectural analysis of built typologies, the re-evaluation and restoration of the monuments of cultural heritage.

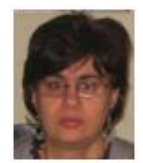

Meri Priftuli (Semini) is an experienced freelance architect in Durres, dealing in housing architectural design and restoration. She received a M.S. degree in Architecture (1991) and she is a guest lecturer at the Faculty of Architecture and Urbanism in Tirana. Her main areas of interest are the housing design, the History of Architecture, and the re-evaluation and restoration of the monuments of cultural heritage. 